\title{
Changes and Innovation of Dutch Building Regulation and Control: An Ongoing Debate
}

\author{
Nico P. M. Scholten ${ }^{1}$ and Rob T.H. de Wildt ${ }^{2}$ \\ 1. Expertise Centrum Regelgeving Bouw (Foundation Expert Centre Regulations in Building), Delft 2628 CS, the Netherlands \\ 2. RIGO (Research Institute for Real Estate) Research en Advies, Amsterdam 1011 AB, the Netherlands
}

\begin{abstract}
Dutch building regulation is under construction. After the report of the commission "Fundamentele Verkenning Bouw" in 2008, several studies have been done on the principals that the commission outlined in its report. Local authorities and parties in construction were invited to start experiments with a more privatized system of building control. But this faced a lack of participation, partly due to the impact of the crisis. The minister responsible for housing and construction invited in 2011 a "Bouwteam" to develop an agenda for action for construction. In 2012, 17 action teams started to focus, speed up and simplify the planning and development of construction. Recently, the two teams related to building regulation presented their plans. The first was a roadmap towards private building control, the second, a proposal for an independent body to answer questions on constructions plans that do intrinsically but not legally meet the standards of building regulation. There is considerable controversy regarding the way that this implementation team is paving its path towards private building control. While the minister for housing conformed himself to a subsidized private implementing team, the Dutch Parliament has expressed its own priorities for regulation: insured guarantee to protect users and owners, a role for local authorities regarding safety and acceptance of buildings and simplification of building regulation and control for simple construction works. The parliament held a round-table conference to get informed about private building control. Recently, a proposal by the minister for housing was discussed. Further debate will be needed to decide about the next steps in innovation building regulation, which will take place in the upcoming months. ERB/RIGO (Foundation Expert Centre Regulations in Building/Research Institute for Real Estate) have developed own proposals for the public-private relation regarding development and construction of buildings. They expect that their proposals might be of help. The proposals are laid down in several publications and partly realized in experimental development of "to be approved" technical solutions. This paper reflects on the differences between their proposals and these of the roadmap, on the possible outcome of the ongoing debate and its implications, legal and technical, on building regulation and on legal and contractual liability. This paper tries to give an inside view on the development of regulation and the pros and cons of the proposals, starting from a theoretical outline of building regulation.
\end{abstract}

Key words: Building regulation, government, innovation.

\section{Introduction}

The Dutch Building Decree has been under discussion for decades. Clear building rules and regulations are an important, even an essential link between building practice and society, aiming primarily at the availability of safe, healthy, usable and sustainable buildings. How effective building rules and regulations are depends largely on their practical applicability, costs and the extent in which they allow building innovations [1].

Corresponding author: Nico P. M. Scholten, Ph.D., research field: building regulations.
With its Building Decree 1992, Dutch legislation took an important first step-a system that meets these objectives. As opposed to the traditional building regulations, the Building Decree does not prescribe in detail how to build, but indicates, the required performance. This system leaves space for the introduction and application of fresh, innovative solutions.

Now more than 20 years later, the building regulations have been changed three times fundamentally, initiated by deregulation initiatives. The last one is more and more based on the idea that governmental regulation can be skipped in the belief 
that market forces will ensure a good performance, in the whole building sector, also for the long run.

Although the Building Decree has proven to be successful in many aspects, various problems have emerged which appear to be structural in origin.

The actual debate concentrates on private building control, as a result from a white paper report in 2008 . Appendix A gives an overview of the related developments in the period of 2008 2014. Parliamentary debates in 2014 marked some first picket posts.

\section{Score So Far in the Political Debate}

The debate resulted in the following main conclusions:

(1) There will not be a choice between public or private building control (as there are now for example in England and Australia);

(2) The date of implementation might be later than January 1, 2017; The legal changes will be careful designed and might take longer;

(3) For the most common building processes ( $80 \%)$ and products, a plan control might no longer be an obligation; It is up to the principal/contractor to meet legal and quality requirements, while the local authority will check if the building meets the legal requirements;

(4) It will be defined which are these common processes and products; It might be a list growing in time;

(5) The consumer will be protected by insured guarantee or a $5 \%$ retention of the construction cost, to be decided yet;

(6) Local authorities will check on Building Decree requirements based on the transfer document of the finished construction. When the result is negative, the building may not be used;

(7) This can be a marginal check when the building followed the approved technical solutions or processes;

(8) Liability for the contractor and developers will be increased; Non-conformity to legal regulation must be banned (reducing 10\% failure costs);

(9) New working methods in construction must be well prepared and developed to guarantee a successful implementation.

Parties appear to interpret the debate in different ways. Therefore, the Commission of MP's (members of parliament) has asked the minister how he will continue his preparation of legal changes.

The minister did bring in procedure in June 2014 a consultation version of the proposed changes in existing laws (Housing Act, Environmental Licensing General Provisions, Bill and Dutch Civil Code BZK (Ministerie van Binnenlandse Zaken en Koninkrijksrelaties (in English: Ministry of the Interior and Kingdom Relations)) 2014. This resulted in 66 most negative reactions. The consultation version was not in line with the five votes on content taken by the parliament. It neglected the opinions of the owners and end-users. Although the minister has declared in the parliament that he advocates the proposal of the experts that has the sympathy of the parliament, it is unclear how the consultation law will underpin that proposal.

\section{Proposals for System Innovation}

On the table, we have two solutions, that of the ministry/implementation team [2,3] and that of the experts in regulation around ERB/RIGO and partners $[4,5]$.

In Figs. 1 and 2, the solutions are illustrated.

In the first model, the building plan control is fully privatized. The construction plans and site will no longer be controlled by the municipality. The assessment of the existing stock by the local authorities can no longer be guaranteed. The private control instruments will be related to the consequence classes of the Eurocodes as risk-based control for all building regulation topics, related to safety, health, usefulness, energy saving and sustainability. During a period of three years, a choice of building control by the municipality or by a private organization has been foreseen (but rejected by the parliament).

The other model is illustrated in Fig. 2. 


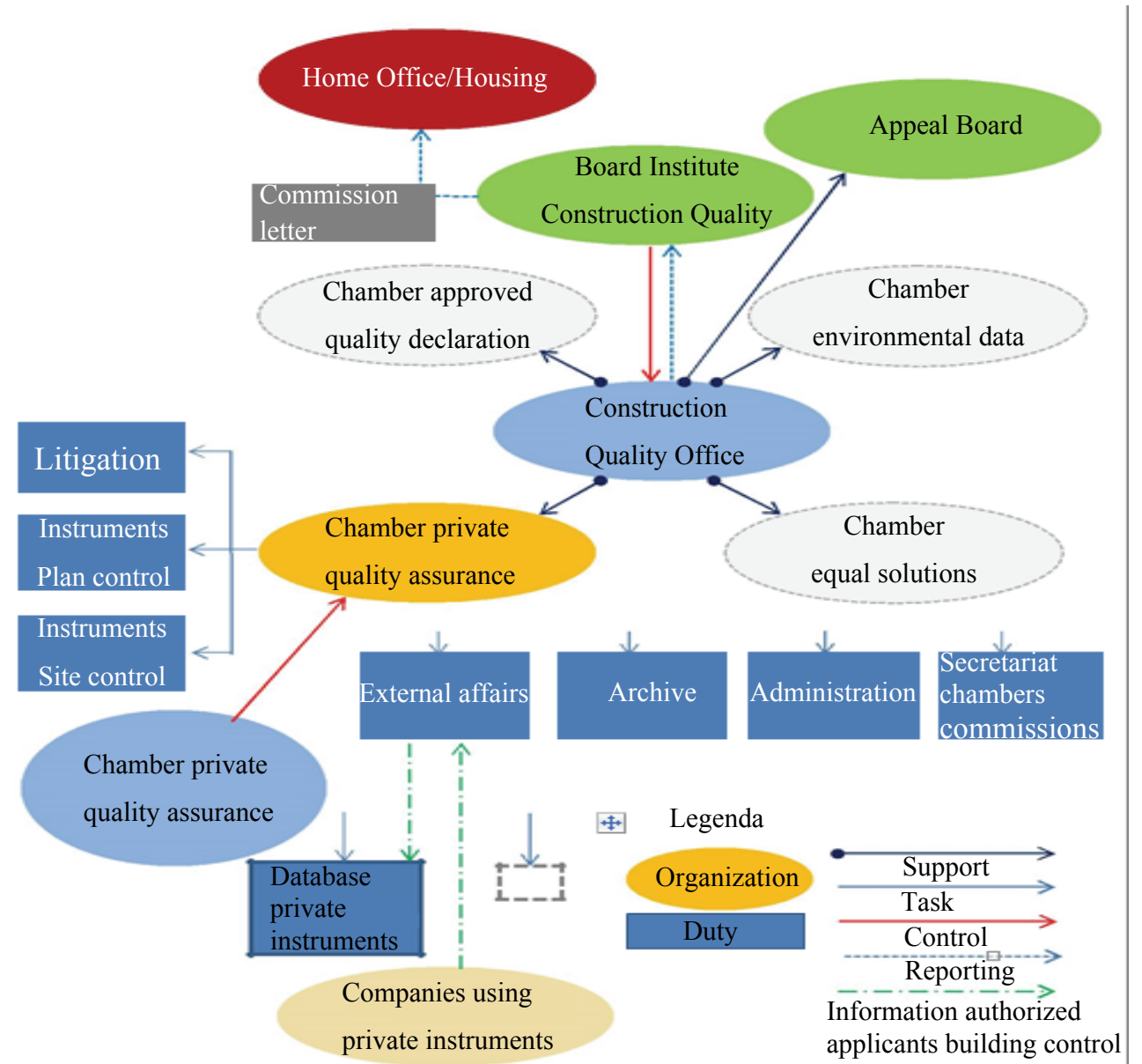

Fig. 1 Model of the "kwartiermakers", February 2014 [3].

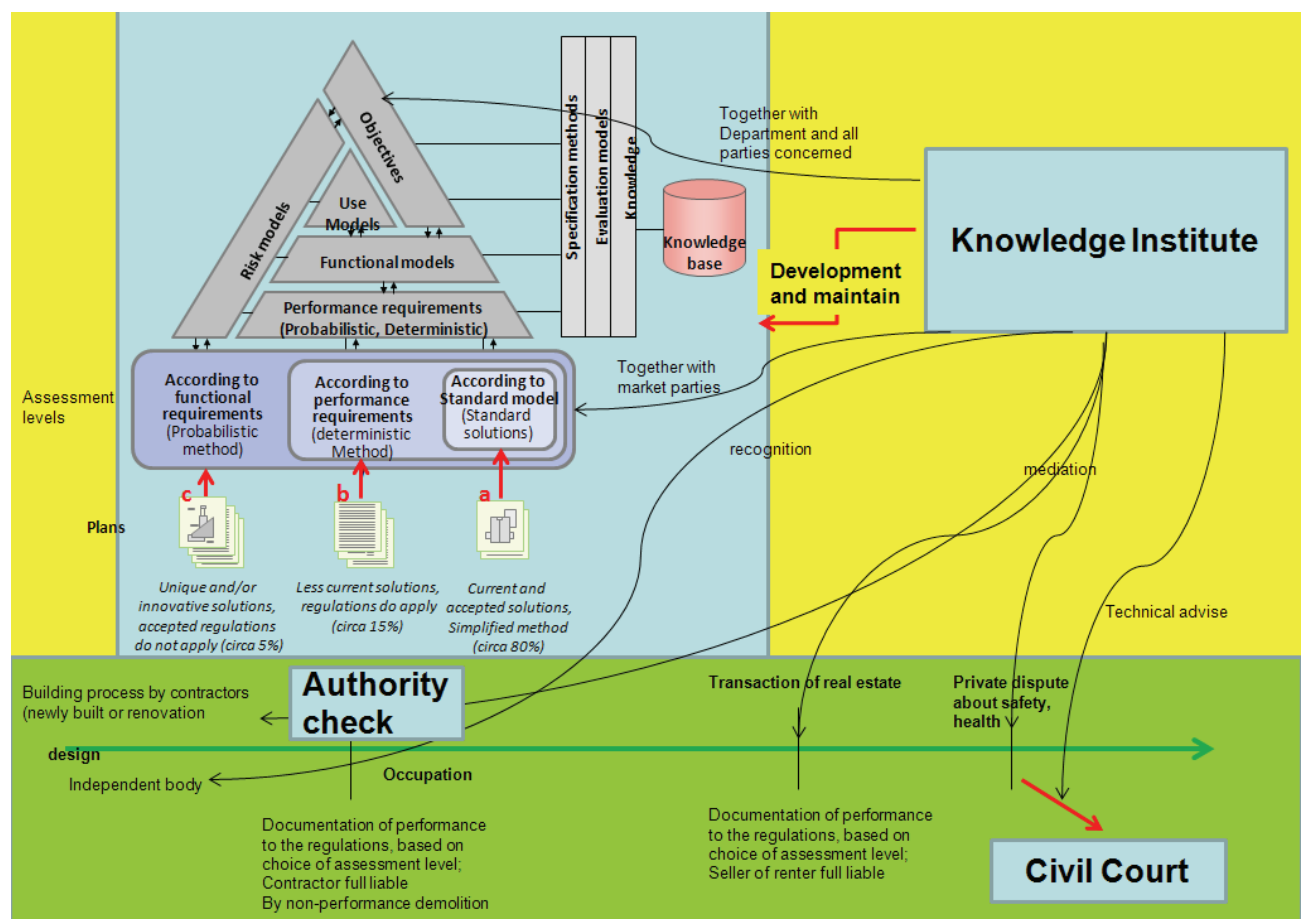

Fig. 2 Model developed by the experts in building regulations. 
Table 1 Comparison of the proposals.

\begin{tabular}{|c|c|c|}
\hline Aspect & Minister/action team & ERB/RIGO and partners \\
\hline Policy-goal & Cost reduction & Interest of user/consumer/owner \\
\hline Moment of control & During planning and construction & As built (at acceptance/start use) \\
\hline Object of control & Building Decree 2012 & $\begin{array}{l}\text { Private contract, minimum standard and the actual } \\
\text { regulation }\end{array}$ \\
\hline Who involved & Private company, starting in dual mode & Local authorities \\
\hline Plan control & $\begin{array}{l}\text { Planning and architectural quality, use of } \\
\text { instruments }\end{array}$ & Planning and architectural quality \\
\hline $\begin{array}{l}\text { Timely involvement, local } \\
\text { authorities }\end{array}$ & Not certain & For more complex constructions \\
\hline $\begin{array}{l}\text { Further development } \\
\text { regulation }\end{array}$ & $\begin{array}{l}\text { Not foreseen (eventually reduction of } \\
\text { rules) }\end{array}$ & $\begin{array}{l}\text { Implementation of approved solutions, and will lead to } \\
\text { more clarity in objectives of regulation }\end{array}$ \\
\hline Risk-based control & $\begin{array}{l}\text { Consequence classes, Eurocodes for all } \\
\text { aspects }\end{array}$ & $\begin{array}{l}\text { Depending on control system (approved solutions, } \\
\text { performance based, probabilistic) }\end{array}$ \\
\hline $\begin{array}{l}\text { Transfer document for local } \\
\text { authorities }\end{array}$ & No & 1 \\
\hline Insurance & Reduced form of third party insurance & $\begin{array}{l}\text { Based on transfer document, can be extended during use of } \\
\text { building }\end{array}$ \\
\hline $\begin{array}{l}\text { Equality of solutions } \\
\text { regarding regulation } \\
\text { (innovative) }\end{array}$ & Not foreseen & Needs a special body, charged with independent judgment \\
\hline Authority & Needed to judge the control instruments & $\begin{array}{l}\text { Non-bureaucratic body, charged with: } \\
\text { - approved solutions; } \\
\text { - probabilistic constructions; } \\
\text { - litigation; } \\
\text { - advisory body for regulation; } \\
\text { professional organizations and companies } \\
\end{array}$ \\
\hline Cost reduction & $\begin{array}{l}\text { Approval fees and some development } \\
\text { time }\end{array}$ & $\begin{array}{l}\text { Reduction in construction failure, estimated } \\
€ 1,000,000,000\end{array}$ \\
\hline Education & No attention & Important redevelopment education needed \\
\hline $\begin{array}{l}\text { Enforcement of regulation } \\
\text { in existing buildings }\end{array}$ & $\begin{array}{l}\text { Local authorities (without documentation } \\
\text { of buildings) }\end{array}$ & Local authorities, based on transfer document \\
\hline $\begin{array}{l}\text { Transparency of data and } \\
\text { developments }\end{array}$ & Not foreseen & $\begin{array}{l}\text { Open access to (objectives of) regulations, approved } \\
\text { solutions, transfer documents }\end{array}$ \\
\hline
\end{tabular}

In the second model, many suppliers produce approved solutions which, when applied in a building, guarantee the performances of the building, at least in line with the building regulations. We expect that, for $80 \%$ of building parts, such solutions could be produced.

In this model, the contractor (principal) is fully responsible to deliver at acceptance of $100 \%$ conformity with the contract that, in any case, applies to the building regulations. At the end, the municipality checks a transfer document that has a complete description of the realization or the renovation of the building, related also to the regulation. If this meets the standards of regulation, the owner gets the permission to use the building.
Insurance is possible based on the transfer document. If the building appears in conflict with regulation or does not deliver the quality as laid down in the transfer document, the owner can make a claim. The insurer will take regress on developer/contractor.

\section{Comparison of the Proposals}

If we compare the actual proposals, we see the differences which are shown in Table 1.

\section{Conclusions}

Following up the discussion in parliament, we foresee a shift towards the ERB/RIGO model, but this is still not certain. Several elements have already been taken up by the implementation team 
(“kwartiermakers”, Institute for Building Quality).

Changing the system in this way and changing the content of the building regulations and the process to develop and maintain the regulations, as mentioned before, creates the possibility of self-regulation and this will result in a leap in knowledge. Most concerned parties will probably take insurance to bear their responsibilities and liability. There is not a legal duty to insure, but the market will push to realize that by itself. That also will strengthen the quality chain. Such an innovated system will give an upward impulse to realize real performances to the level that the market expects. This system will only function when the knowledge chain is closed (Fig. 3).

On the other hand, there still are strong forces to implement a private building control system that mirrors the actual public planning control. Experiences abroad (Scandinavia and Iceland) have shown that this does not protect the users of buildings against poor quality and gives no guarantee that regulations are fulfilled. The proposals of the implementation team bring private duties in the public arena and make the minister and municipality responsible for private quality assurance of market parties. That is not the role of the government and authority.

The implementation of ERB/RIGO proposals will create new functions. Acknowledgments should be organized for independent technical-legal arbitration in a way that parties which have a conflict on technical points can quickly settle the dispute on technical-legal arguments. The actual road of litigation and appeal is much too cumbersome.

Furthermore, knowledge should be easier accessible and actively promoted through training, publication, the internet and knowledge systems. It will be transferred to professionals in the building chain, as well as the law enforcement organizations.

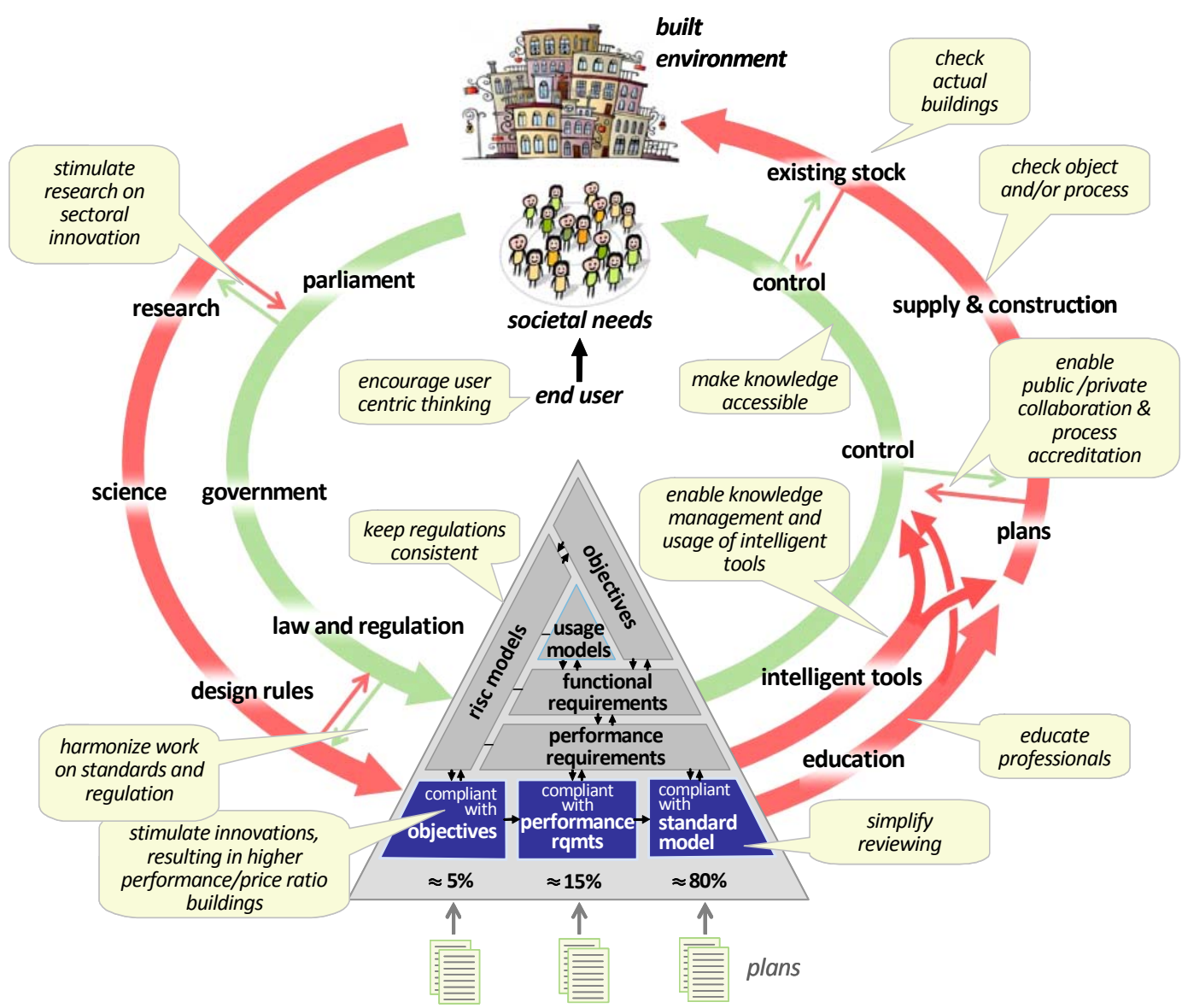

Fig. 3 Vision on future development of building regulations in closed and linked public and private law chains of knowledge [6]. 
Moreover, emphasis could shift from design to process assessment and possibly to process certification. That shall cover the complete process from design to the building process, including quality management and guarantee after acceptance/completion. This quality related thinking (ISO9001) has been accepted in many sectors of industry, but what would this mean for the structurally so fragmented building sector? The ultimate test in quality related thinking is customer satisfaction. But as already stated, the actual customer, the end user, generally takes no part in the Dutch building process, except the scarce homebuilding principal. Designers, contractors, suppliers and authorities have split responsibilities: Nobody feels accountable for the whole process. Although integrated contracts are becoming more popular-partly as a consequence of the need of integral accountability - they still only constitute a small part of the present market of construction and certainly of refurbishment.

With this coherent approach, methodical improvements can be implemented and monitored leading to a more consistent practice that, by means of reference, can become part of the same chain of knowledge and experience.

\section{References}

[1] Scholten, N. P. M. 2001. "Technical and Juridical Foundations of the Technical Building Regulations-Housing Act and Building Decree.” Ph.D. thesis, Technical University Delft.

[2] Actieteam. 2013. Roadmap to Privatized Building Control. Rotterdam-Utrecht: Actieteam. (in Dutch)

[3] Institute for Building Quality (Implementation Team). 2014. On the Road to an Admission Organization (for Privatized Building Control. Rotterdam: Institute for Building Quality (Implementation Team). (in Dutch)

[4] Scholten, N. P. M, De Wildt, R., Vrouwenvelder, A. C. W. M. 2011. After Dekker-Innovation of the Building Regulations. Delft: ERB (Foundation Expert Centre Regulations in Building)-RIGO (Research Institute for Real Estate)-TNO (Research Institute for Applied Science). (in Dutch)

[5] Scholten, N. P. M, and De Wildt, R. 2013. Approved Technical Solutions, Quick Scan. Delft: ERB (Foundation Expert Centre Regulations in Building)-RIGO (Research Institute for Real Estate)-NEN (Dutch Standardization Institute)-STABU (Foundation for Specification System for the Dutch Building Industry). (in Dutch)

[6] Scholten, N. P. M., Gielingh, W. F., Vrouwenvelder, A. C. W. M., Groosman, M., Heijden van der, J. J., and Willebrands, D. 2010. Trust and Reliability, Part II: A Plan for the Innovation of the System of Building Regulations. Delft: ERB (Foundation Expert Centre for Building Regulations). (in Dutch) 


\section{Appendix A: History and studies.}

In 2008, the commission "Fundamentele Verkenning Bouw" produced its report "private if possible, public if necessary—trust and responsibility in the building process", ${ }^{1}$ followed by a few underpinning research reports. ${ }^{2}$ Changes of ministers (five since 2008) and cabinets prevented the implementation of a new regime with less public building control. Further studies took place. ${ }^{3}$

The crisis had especially in 2011 2013 a strong negative impact on Dutch construction. Housing was confronted with a double dip, due to uncertainty over fiscal measures and financing.

In 2011, the minister for Housing/Home Office institute a Bouwteam to report on measures to promote construction. ${ }^{4}$ This leads to the formation of 17 private action teams (with governmental support). Two were of importance for building regulation:

(1) Actieteam Private Bouwplantoetsing (private building control) that reported in July 2013; ${ }^{5}$

(2) Actieteam Praktijktoepassing Bouwbesluit (practical application Building Decree), reported in January 2014 . $^{6}$

In 2013, the ministry commissioned also a social cost-benefit analysis (MKBA) of private building control. ${ }^{7}$

The consortium ERB/RIGO/TNO has on its own initiative and in a debate with many experts involved in the construction industry tried to translate a preliminary outline for the private and public roles in construction related regulation into a realistic approach. The preliminary outline dated from 2009: "Vertrouwen en Betrouwbaarheid”. ${ }^{8}$ In 2011, a quick scan was made for the Ministry of Housing to elaborate this. ${ }^{9}$ This was extended in 2013 to a study on approved technical solutions and the possibilities to implement these.

On the basis of the ideal model, we are able to clearly illustrate the practice related hitches. Fig. A1 charts these hitches (a till h). ${ }^{10}$

In the second half of 2013, the debate on private building control became more frenzy. The roadmap of the action team started a discussion on its pros and cons.

The main factor of private building control is the responsibility for the principal/contractor to meet the requirements of the Building Decree. Neither the local authorities nor the contractors are very favorable towards this goal of privatization. The roadmap foresees a three-year period of choice between private or public building control. The professional principals are the main supporting group, they expect cost savings in building control fee. Local authorities expect a difficulty in resource planning. Local authorities see an important future problem: They will not be able to check if an existing building has a risk of non-conformity against the Building Decree, while this is their duty, laid down in the Housing Act.

ERB/RIGO/TNO propose a different way to come to private building control. Key factor is that the completed building must meet the requirements of the Building Decree, which has to be shown to the local authorities with a construction record: A dossier that shows what has been build and how the quality has been controlled. A construction license can be limited to the proof that the building meets planning regulations. Non-conformity may have the effect that use of the building is not allowed.

\footnotetext{
1“Private What Can, Public What is Necessary, Trust the Responsibility in the Building Process.” May 14, 2008, Commission Fundamental Survey Building Sector. (in Dutch)

2"Motivations of Stakeholders for the Use of Privatizing Building Control in the Public Sector.” August 8, 2012, Spekkink C\&R. (in Dutch); "Risk Responsibility as Substitute for Public Building Control?” June 21, 2012, Crisislab. (in Dutch); "The Market as Supervisor-Private Quality Control in the Building Process.” July 2012, Foundation Building Quality. (in Dutch)

"To Another Segmentation of Responsibility in the Building Sector.” February 2013, Institute for Contrition Law. (in Dutch); “Quick Scan Authority Private Building Control.” June 21, 2013, Brink Groep. (in Dutch)

4"The Building Sector in Action(s) - Investment and Innovation Agenda for Housing and Utility Sector in the Building.” Building Team, May 2012. (in Dutch)

5“Key Map to Private Building Control.” July 2013, Action Team Private Building Control. (in Dutch)

6“"Flexible Handling Building Regulations.” Action Team Practical Application Building Decree, January 13, 2014. (in Dutch)

7"SCBA Privatizing of the Quality Control in the Building Process.” September 23, 2013, Ecorys. (in Dutch)

8“Trust and Reliability, Part I, A Vison on the Functionality of the Building Regulations.” January 2009, ERB. (in Dutch); “Trust and Reliability, Part II, A Design for Innovation of the System of Building Regulations.” September 2012, ERB. (in Dutch)

9"Further after Dekker-Innovation of the Building Regulations—Quick Scan.” Report R.2011/ERB R/001, September 17, 2011, ERB/RIGO/TNO. (in Dutch)

10“A Need to Innovate the Dutch Building Regulation.” 2012. Rics Cobra, Las Vegas, Nevada USA , September 11-13, 2012, Dr. N. P. M. Scholten, Ph.D., R. De Wildt, M.Sc., Frics and Prof. A. C. W. M. Vrouwenvelder. (in Dutch)
} 


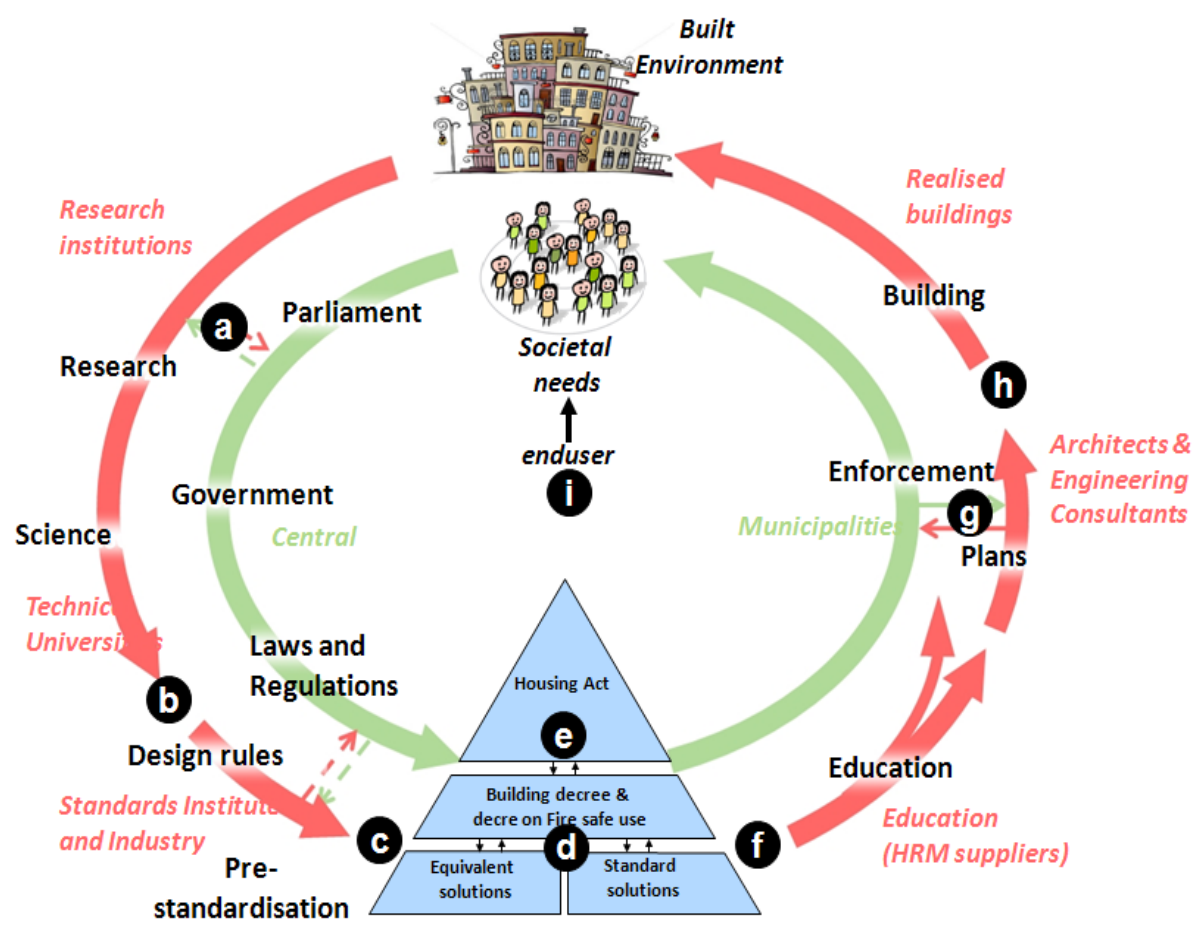

Fig. A1 Hitches in the knowledge circle. ${ }^{11}$

ERB/RIGO organized two debates, the first about the main principals and clear roles of private and public sector, while the second about the possibilities for the approved technical solutions.

Several other construction bodies expressed their concerns regarding a not-well-designed implementation of a private building control at choice of the principal: local authorities, civil servants in building control, fire brigade and structural engineers.

In October 2013, the implementation team founded the Institute for Construction Quality as a vehicle to its activities. It is not clear if this is a self-employed foundation or it is working with support of the ministry.

While the ministry developed its policy and sent a proposal for implementation to the parliament, ${ }^{12}$ the parliament expressed its view in four Second-Chamber motions, in favour of insured guarantees, a role for local authorities regarding safety, an formal document/dossier to be delivered to and judged by the municipality before use and a scaled use of regulation: simple for simple and manifold made constructions and more deeply studied for complex and innovative buildings.

To prepare the debate, there was a hearing session in December 2013, in which an a long list of questions would be answered by the minister. The debate took place at the end of March 2013 and the result is not yet clear: The implementation will be different form earlier ideas and has to be reworked. A phased implementation might take place, starting with approved solutions.

ERB/RIGO made earlier a study into approved technical solution, together with the institutions for normalization (NEN) and STABU (standard building contract documents), ${ }^{13}$ which was also discussed with representatives of the construction industry. The minister did send the report to the parliament after some pressure from MP’s (members of parliament). ${ }^{14}$

\footnotetext{
${ }^{11}$ Scholten, N. P. M., Gielingh, W. F., Vrouwenvelder, A. C. W. M., et al. 2010. "Trust and Reliability, Part II: A Plan for the Innovation of the System of Building Regulations.” Delft: ERB. (in Dutch)

${ }^{12}$ TK 32 757, 91, "Letter Addressed to the Parliament about Strengthening the Quality Assessment in the Building Process." November 27, 2013. (in Dutch)

${ }^{13}$ Approved Technical Solutions: Deemed to Satify/Till Usefulness and Pleasure of the End-User-Quick Scan of the Development of Approved Technical Solutions in Line with the 2012 Building Decree for 80\% of the Building Practice. Report R.2013/ERB-R011, November 29, 2013, ERB/RIGO/NEN/STABU. (in Dutch)

${ }^{14}$ TK 32 757, 912, “Letter Addressed to the Parliament Related to Approved Technical Solutions.” February 7, 2014. (in Dutch)
} 
In a few newsletters, ERB and RIGO elaborated on several aspects of the possible changes in building regulations. Topics were the division in three types of construction (common works, performance-based, probabilistic), the necessary protection of the user, an analysis of private building control abroad, the possibilities of insurance and guarantee, equal solutions, approved technical solutions and the logic behind private building control in a legal framework. ${ }^{15}$

\footnotetext{
${ }^{15}$ Publication 2013-ERB-P040. "Effect Regulations by Using the 5-15-80 Ideas-Examples.” www.omgevingsweb.nl/. (in Dutch) Publication 2013-ERB-P048. “The Construction Industry the Apples, the End-User the Baked Pears?” www.omgevingsweb.nl/. (in Dutch)

Publication 2013-ERB-P055. "Private Reviewing an Assessment of the Construction Sector Abroad.” www.omgevingsweb.nl. (in Dutch)

Publication 2013-ERB-P056. “Further after Dekker-Innovation of the Building Regulations: Insurability.” www.omgevingsweb.nl. (in Dutch)

Publication 2014-ERB-P002. "Further after Dekker—Innovation of the Building Regulations: Equalness.” www.omgevingsweb.nl. (in Dutch)

Publication 2014-ERB-P005. “Quick Scan Approved Solutions has Broad Support.” www.omgevingsweb.nl. (in Dutch)

Publication 2014-ERB-P010. "Privatized Building Control: The (im)possibilities in the (on)logic.” www.omgevingsweb.nl. (in Dutch)
} 